\title{
Az egészséggel kapcsolatos naiv elméletek, tévképzetek egy próbamérés tapasztalatai alapján
}

\section{Naive theories and misconceptions related to health based on a pilot study}

\author{
Szerzők: $\quad$ Lipták Mónika Zoéa $\varangle$, Dr. habil. Tarkó Klárab \\ a: Szegedi Tudományegyetem Bölcsészettudományi Kar Neveléstudományi Doktori Iskola \\ b: Szegedi Tudományegyetem Juhász Gyula Pedagógusképző Kar Alkalmazott \\ Egészségtudományi és Egészségfejlesztési Intézet
}

Beküldve: 2020. 04. 22.

doi: $\quad$ 10.24365/ef.v61i2.590

\begin{abstract}
Összefoglaló:
Bevezetés: Jelen kutatás célja az volt, hogy felmérje, milyen tévképzetekkel rendelkeznek az egészséggel kapcsolatban a pedagógiai, szociológiai és egészségügyi szakterületen tanuló hallgatók, illetve hogy ezek a tévképzetek milyen forrásból származnak. Ezen kívül kíváncsiak voltunk a megkérdezett hallgatók egészségfogalmára, hogy milyen kép él bennük, ha meghallják az egészség szót. Kutatásunkkal a leendő pedagógusok egészséggel kapcsolatos tévképzeteinek vizsgálatára irányuló nagymintás mérésünk kérdőívének első változatát próbáltuk ki.

Módszertan: A méréshez felvett minta teljes elemszáma 68 fő volt. Az anonim, önkitöltős, online kérdőívünk az egészség értelmezésére vonatkozó nyitott, valamint az egészséggel kapcsolatos tévképzeteket vizsgáló feleletválasztós kérdéseket tartalmazott, kiegészítve a válaszadók szocio-demográfiai jellemzőit vizsgáló kérdésekkel. Elemzéseinket az SPSS statisztikai programcsomag segítségével végeztük el. A mérés eredményeire alapozott, jövőbeni vizsgálatunkat magyar felsőoktatási intézményekben a pedagógusképzésben tanuló hallgatók közremúködésével kívánjuk lefolytatni. Összesen 1000 fő részvételére számítunk.

Eredmények: A holisztikus egészségdimenziók közül a fizikai egészségdimenzió túlsúlya jellemzi a válaszadók egészségfelfogását. A mintaátlag szerint helyesen látták, hogy az életmód játssza a legfontosabb szerepet az egészségük alakulásában. Az egészségtévképzetek vizsgálatára szolgáló 37 állítás közül 23 esetben (62\%) megjelentek a minta szintjén a téves elképzelések. Meglévő egészségtévképzeteik fő forrása a média és a családtagok.
\end{abstract}

Következtetések: Az egészség értelmezésének, valamint az egészséggel kapcsolatos tévképzeteknek és forrásaiknak a vizsgálata leendő pedagógusok körében fontos, mivel a köznevelésben a pedagógusoknak közvetlen hatása van a gyerekek és fiatalok egészségképére.

Kulcsszavak: tévképzet; egészség; holisztikus egészségdimenziók

\section{Summary:}

Introduction: The aim of this study was to survey the health misconceptions and their sources in higher education students studying educational, sociological, and health sciences. We also investigated their health concept and the associations relating to 'health'. Our research is the first stage of a planned large-scale survey on the health misconceptions of future educators. 
Methods: The sample consisted of 68 participants. The anonymous, self-administered questionnaire contained open-ended questions referring to the participants' understanding of health, as well as multiple-choice questions on health misconceptions, together with background socio-demographic questions. Data analysis was done with the help of the SPSS statistical package. Based on the present study we would like to carry out large-scale research among university students studying education. We expect the participation of 1000 respondents.

Results: From among the holistic health dimensions the predominance of the physical health characterizes the respondents' perceptions of health. According to the means of scores, they correctly considered lifestyle playing the most important role in the promotion of their health. From among the 37 given health statements misconceptions appeared in 23 cases (62\%). The main source of their health misconceptions were the media and their family members.

Conclusions: Studying the health concept, health misconceptions, and their sources among future teachers are very important, as educators have an immediate effect on the health concept of children and young people.

Keywords: misconception; health; holistic health dimensions

\section{BEVEZETÉS}

A tévképzet fogalma igen tág határok között mozog, az alapja lehet babona, mítosz, népi hagyományok vagy félreértések. Téves értelmezésből vagy a tények alapos megfigyelésének hiányából eredhet, de tükrözheti az információ puszta hiányát is. ${ }^{1}$ A fogalmak olyan elképzelések, tények vagy események, amelyek segítenek megérteni a körülöttünk lévő világot. ${ }^{2}$ Sexton és Gerlovich szerint a téves elképzelések azonban olyan elképzelésekként írhatók le, amelyek tapasztalatokon alapulnak, és téves fogalomdefiniáláshoz vezetnek. ${ }^{3}$ Hasonlóságot vettek észre a kutatók az egyes diákok hibás válaszadásai között, ezek nagy része nem véletlen, sőt kategória szerinti besorolást is tudunk alkalmazni a hibás elképzelések típusai alapján. Mindezekből arra lehet következtetni, hogy a diákok fogalmi hálójában azonos módon rendeződött, hibás részek vannak. ${ }^{4}$ A naiv elképzelések stabilak, nem könnyú a megváltoztatásuk, mélyrehatók, a tanulást nehezíthetik. Az, hogy a gyermek hány éves, milyen nemú, milyen az iskolai teljesítménye és a képessége, nem annyira vagy csak kevésbé befolyásolja a tévképzetek kialakulását és gyarapodását, valamint nehéz feltérképezni jelenlétüket. ${ }^{5}$

Az egészség tudományos kategória és hétköznapi fogalom egyszerre. A tudomány evolúciója az egész- ségfogalom paradigmaváltását hozta, a betegség hiányából kiinduló egydimenziós, objektív, organikus, individuális, statikus értelmezést felváltotta a pozitív, többdimenziós, szubjektív, személyes, szituatív és dinamikus megközelítés. ${ }^{6}$ Pozitív abban a tekintetben, hogy nem valaminek, nevezetesen a betegségnek a hiányából indul ki, hanem a testi, lelki, szociális, spirituális és ökológiai jóllétet helyezi középpontba.7 Már az előbb említett tényezők kiemelése is jelzi, hogy többről van szó, mint a testi egészség; a többdimenziós megközelítést még személetesebben foglalja össze a holisztikus egészségfogalom, a maga testi, mentális, érzelmi, spirituális, társas és társadalmi dimenzióival. ${ }^{8,9}$

Az egészségtévképzetek torz vagy hamis elképzelések az egészséggel kapcsolatos kérdésekről. ${ }^{10}$ A szakirodalmi áttekintést követően fény derült arra, hogy a különböző, fóként természettudományos diszciplínák esetében több kutatás is folyt már Magyarországon a tévképzetek vonatkozásában ${ }^{4,11,12,13}$, de míg a laikus egészségfogalom széles körben kutatott ${ }^{14,15,16}$, addig az egészséggel kapcsolatos tévképzetek tanulmányozására ez idáig nem láttunk példát. Az egészséges életmódra nevelés, az egészségfejlesztés jelenleg transzverzális készségként van jelen a köznevelésben, elvárva minden pedagógustól, illetve kiemelten a testnevelés és a biológia tanároktól az egészségnevelési tartalmak 
közvetítését. Meglátásunk szerint azonban a pedagógusképzés nem készíti fel a leendő szakembereket erre a nemes feladatra.

A fenti helyzetből kiindulva nagymintás kutatással kívánjuk feltérképezni a leendő pedagógusok egészségfelfogását, valamint az egészséggel kapcsolatos tévképzeteiket, és ennek alapján javaslatokat szeretnénk megfogalmazni a pedagógusképzésbe bevezetni szükséges egészségfejlesztési tartalmakra nézve.

Első hipotézisünk szerint a leendő pedagógusok egészségfogalma nem tükrözi a modern, holisztikus egészségértelmezés komplexitását, abban életkorra, nemre, családi háttérre, szakosodásra való tekintet nélkül a fizikai egészségdimenzió túlsúlya figyelhető meg. Második hipotézisünkben azt fogalmaztuk meg, hogy a leendő pedagógusok egészséggel kapcsolatos tévképzetei különböznek az életkor, a nem, a családi háttér, a felsőoktatási intézmény típusa és a szakosodás függvényében. Végül harmadik hipotézisünk szerint a leendő pedagógusok egészségfogalmát, egészségtévképzeteit a laikus (szülők, barátok, ismerősök stb.), valamint a populáris (média, közösségi média) információforrások alakítják, a formális képzés (köznevelés, felsőoktatás) nem játszik jelentős szerepet.

E nagymintás mérés előkészületének első állomásaként próbamérést végeztünk online platformokon egyszerúen elérhető alanyokra támaszkodva. A kutatás etikai engedélyét a Szegedi Tudományegyetem Neveléstudományi Doktori Iskola Etikai Bizottsága adta, az engedély száma: 14/2018. A következőkben a próbamérésre vonatkozó kutatási elrendezésünket és néhány eredményünket mutatjuk be.

\section{MÓDSZERTAN}

Minta

Mérésünkhöz könnyen elérhető alanyokat kerestünk, ezért a Google kérdőívkészítő segítségével összeállított, online kérdőívünk linkjét osztottuk meg közösségi platformokon. Első körben a részvétel feltételeként csak annyit adtunk meg, hogy a jelentkezők magyar felsőoktatásban tanuló hallgatók lehetnek, preferáltan azok, akik a pedagógusképzésben vesznek részt.

\section{Kérdőív}

Mérőeszközünk nem tartalmazott személy azonosítására vonatkozó kérdést. A kérdőív kérdéseit szakirodalmi kutatómunkára alapozva állítottuk össze. Először a válaszadók egészségfogalmát térképeztük fel a következő nyitott kérdés segítségével: „Milyen kép jut az eszedbe először, amikor meghallod az egészség szót? Meséld el, hogy mit látsz a képen, és írj hozzá egy rövid indoklást!" A nyitott kérdésre megfogalmazott válaszokat a holisztikus egészségfogalom hat dimenziója alapján kategorizáltuk. A kódolást egymástól függetlenül, párhuzamosan végeztük el, majd azokat összevetve konszenzussal véglegesítettük besorolásunkat. A válaszok a holisztikus egészségdefiníció elemeinek megfeleltethető konkrétumokat tartalmaztak (pl. étkezés, orvoshoz fordulás, futás, mozgás, kirándulás, boldogság, család együtt stb.).

Második kérdésünk az egészséget meghatározó tényezők százalékban kifejezett súlyát vizsgálta, ugyancsak nyitott kérdés segítségével. Lalonde ${ }^{17}$ kanadai egészségügyminiszter vizsgálata óta egyre szélesebb körben ismeretes, hogy egészségünk alakításában az életmódunk szerepe a leghangsúlyosabb. Annak vizsgálatára, hogy válaszadóink hogyan látják e meghatározottságot, a következő kérdést tettük fel: „Van összesen 100 egészségpontod, amit szét kell osztanod az alábbi 4 tényező között aszerint, hogy mekkora hatással lehetnek az egészségedre. Hány pontot adnál nekik? Mind a 100 pontot szét kell osztanod!"

Harmadik, az egészségtévképzetek vizsgálatára irányuló kérdéscsoportunk összeállításához szakirodalmi kutatómunka alapján feltérképeztük azokat az egészséggel kapcsolatos álításokat, melyek a leggyakoribb tévképzeteket tükrözik. A szakirodalmi elemzés nyomán gyűjtött, gyakori tévképzetek fellelhető listáit áttekintve azok közül a hiteles tudományos vizsgálatokkal is egyértelműen igazolt egészségállításokat választottuk ki. Összesen 40 olyan állítást fogalmaztunk meg, melyekkel való egyetértés vagy éppen egyet nem értés foka az adott egészségállítással kapcsolatos téves elképzeléseket, tévképzeteket tükrözi. 
Az egyes állításokkal való egyetértés fokát ötfokozatú Likert skálán mértük, mely az egyáltalán nem igaztól (1-es érték) a tökéletesen igazig (5-ös érték) terjedt (közbülső értékek jelentése: 2-es érték nem igaz; 3-as érték - részben igaz; 4-es érték igaz). Kérdőívünk első verziójában felsorolt állítások közül 37-et mutatunk be eredményeink ismertetésekor. Három esetben úgy láttuk, hogy a szakirodalom ellentmondásos volta miatt azok megítélését nem tudjuk megfelelően értékelni (6. Fittebb leszek, ha pár étkezést kihagyok, 11. Ha rossz napom van, jobban fogom érezni magamat, ha eszek valami finomat, 22. Minden nap 8 pohár vizet kell meginni.) Az egyes állításokra az összes válaszadó által adott 1-5-ig értékkel rendelkező válaszok számtani átlagát képeztük, valamint minden esetben megadtuk a móduszt is, ami azt jelöli, mely értéket választották a legtöbben az egyes állításoknál, és a mediánt, amely azt az értéket jelzi, amelyet vagy annál alacsonyabb (magasabb) értéket a válaszadók 50\%a választott. Ezzel az egyszerű, leíró statisztikai elemzéssel első körben arról szerettünk volna becslést kapni, hogy a válaszok átlagosan mennyire tükröznek téves elképzeléseket. Eredményeink ismertetésekor azt is jelöltük, hogy az állítás hamis, vagy inkább hamis (H), illetve igaz-e (I). Mivel arra törekedtünk, hogy a viszonyítási alapunk mindig olyan állítás legyen, mely referált, lehetőleg impakt faktoros folyóiratban közölt tudományos eredményeket tartalmaz, tévképzetnek, téves elképzelésnek neveztük azt, amikor a válaszadók rosszul itélték meg adott állítások helytállóságát. Vannak állítások, melyek rendelkeznek igazságtartalommal, de a jelen megfogalmazásban önmagukban nem igazak, mert nem fejezik ki a jelenség összetett voltát, így ezeket inkább hamisnak tekintettük (pl. „Az elhízás hátterében genetikai okok vannak” vagy „A kövér emberek azért túlsúlyosak, mert sokat esznek"ezek mind lehetnek okok, de egyikről sem lehet kijelenteni önmagában, hogy csakis ezek igazak; „A palackozott víz egészségesebb, mint a csapvíz" ez attól is függ, hogy PET vagy üveg palackról van szó). A hamisnak vett állításoknál minél magasabb értéket mutat 2-esnél az átlag, a módusz és a medián, az annál inkább téves elképzeléseket jelez. Ugyanígy, az igaznak vett állításoknál, a 4-es értéknél minél alacsonyabb értéket mutat az átlag, a módusz és a medián, az annál inkább téves elképzeléseket jelez. Végezetül a válaszadók szociodemográfiai hátterét kutató nyitott és zárt kérdéseket tettünk fel.

\section{EREDMÉNYEK}

Felhívásunkra összesen 68 felsőoktatásban tanuló hallgató töltötte ki a kérdőívünket a megadott kéthetes periódusban, és a kitöltők között nemcsak pedagógiai, hanem szociológiai és egészségügyi szakterületeken tanuló hallgatók is voltak. A kitöltők között mindösszesen 5 (7,4\%) férfi volt. A válaszadók átlagéletkora 27,9 év (SD: 7,93).

\section{Egészségfogalom és az egészséget befolyásoló tényezők megjelenése}

A minta egészségfogalmára vonatkozóan kapott eredmények egyértelmúen az első hipotézisünket igazoló irányba mutatnak, miszerint a válaszadók egészségfelfogását a fizikai egészségdimenzió túlsúlya jellemzi. [1. táblázat]

1. táblázat: Holisztikus Egészségfogalom dimenzióinak megjelenése

\begin{tabular}{|c|c|}
\hline Holisztikus egészégdimenziók & Megjelenési arány a képeken (\%) \\
\hline fizikai & 95,2 \\
\hline érzelmi & 31,7 \\
\hline társas & 17,5 \\
\hline spirituális & 9,5 \\
\hline mentális & 7,9 \\
\hline társadalmi & 1,6 \\
\hline
\end{tabular}

Forrás: saját szerkesztés 
Egy-egy válaszadó az egészség több dimenzióját is megjeleníthette, így az egyes dimenziók \%-os összegzése meghaladja a 100\%-ot. Fizikai dimenzióba soroltuk a mozgással, táplálkozással, fizikai egészségi állapottal kapcsolatos leírásokat.

A 2. táblázatban mutatjuk be azt, hogy az egészséget befolyásoló tényezők fontosságát hogyan értékelték válaszadóink.
Az életmódra vonatkozó átlag adatunk (43\%) a szakirodalmi arányokat eredményezte, tehát a válaszadók átlagban helyesen látják az életmód fontosságát. A szakirodalmi értékekhez képest a genetika szerepét 3 százalékponttal alulbecsülték (24\%), míg a környezeti hatások (20\%) és az egészségügyi ellátórendszer (13\%) vonatkozásában felülbecslés mutatkozott.

2. táblázat: Egészséget befolyásoló tényezők

\begin{tabular}{|c|c|c|}
\hline & $\begin{array}{c}\text { \%-os megoszlás (szórás) - } \\
\text { kutatás }\end{array}$ & $\begin{array}{c}\% \text {-os megoszlás (szórás) - } \\
\text { szakirodalom }\end{array}$ \\
\hline életmód & $43 \%$ (SD: 17$)$ & $43 \%$ \\
\hline genetika & $24 \%($ SD: 16$)$ & $27 \%$ \\
\hline környezeti hatások & $20 \%$ (SD: 9$)$ & $19 \%$ \\
\hline egészségügyi ellátórendszer & $13 \%$ (SD: 7$)$ & $11 \%$ \\
\hline
\end{tabular}

Forrás: saját szerkesztés

\section{Egészséggel kapcsolatos tévképzetek}

A következőkben bemutatjuk, válaszadóink hogyan értékelték az általunk felsorolt egészségállítások igazságtartalmát. [3. táblázat] Látható, hogy a megnevezett 37 állítás közül 23 esetben (62\%) megjelentek a minta szintjén a téves elképzelések.
Mindegyik egészségállítás esetében arra is választ vártunk, honnan, kitől hallotta a válaszadó az adott információt, hogy ezáltal képet kaphassunk arról, mely információforrás(ok) gyakorolják a legnagyobb hatást válaszadóinkra, tévképzeteik honnan származhatnak. A kapott válaszok számszerűsítése még folyik.

3. táblázat: Egészségállítások és a teljes mintára számított átlag és módusz ( $n=68$ fő)

\begin{tabular}{|c|c|c|c|c|}
\hline Állítás & $\mathrm{V} / \mathrm{H}$ & átlag & $\begin{array}{l}\text { módusz } \\
\text { (fö) }\end{array}$ & medián \\
\hline $\begin{array}{l}\text { 1. Az emberi test olyan, mint egy gép. Ha elromlik, az orvos } \\
\text { megjavítja. }\end{array}$ & $H$ & 2,47 & $3(41)$ & 3 \\
\hline $\begin{array}{l}\text { 2. Az elme, a test és a lélek összhangja szükséges ahhoz, hogy } \\
\text { egészségesek legyünk. }\end{array}$ & I & 4,40 & $5(36)$ & 5 \\
\hline 3. A sok idegeskedéstől megbetegszik az ember. & I & 4,12 & $5(28)$ & 4 \\
\hline $\begin{array}{l}\text { 4. Ha megbetegszik az ember, csak bekap egy gyógyszert és } \\
\text { meggyógyul. }\end{array}$ & $\mathrm{H}$ & 1,94 & $1(24)$ & 2 \\
\hline 5. A betegségekért főként a vírusok és a baktériumok felelősek. & $H$ & 2,95 & $3(52)$ & 3 \\
\hline $\begin{array}{l}\text { 7. Ha egy étel csomagolásán az szerepel, hogy egészséges, } \\
\text { akkor biztosan az. }\end{array}$ & $H$ & 3,16 & $3(32)$ & 3 \\
\hline 8. A rostos üdítő egészségesebb a szénsavas üdítőknél. & $\mathrm{H}$ & 2,13 & $2(27)$ & 2 \\
\hline
\end{tabular}


9. A diétás üdítő egészséges.

10. Nincs kapcsolat aközött, hogy hány órát alszom, és mennyi a súlyom.

12. Ha eleget mozgok, nem kell odafigyelnem arra, hogy mit eszek.

13. Egészséges vagyok, szóval azt ehetek, amit csak szeretnék.

14. A kövér ember csakis magának köszönheti, hogy ilyen lett.

15. Nem baj, ha gyerekként nagyobb a súlyom, majd kinövöm.

16. Minél nagyobb súlyú valaki, annál több ételre van szüksége ahhoz, hogy egészséges maradjon.

17. A fittség azt jelenti, hogy vékony vagyok, és jól nézek ki.

18. Minél keményebben edzek, annál többet teszek az egészségemért.

19. Ha véletlenül leesett egy falat a padlóra, semmi bajom sem lesz, ha felveszem és megeszem.

20. A cukor függőséget okozhat.

21. Ha sok répát eszel, jobb lesz a látásod.

23. A másnaposság legjobb ellenszere, ha iszunk egy kis alkoholt.

24. Az alkohol elpusztítja az agysejteket.

25. A cukorbetegséget a túl sok cukros étel fogyasztása okozza.

26. A stressz magas vérnyomást okoz.

27. A tejfogak ápolása nem olyan fontos, úgyis kihullanak.

28. A kismamáknak kettő helyett kell enniük.

29. A cukorbetegség az elhízás következménye.

30. A cukorbetegek nem sportolhatnak.

31. A dohányzásról könnyü leszokni.

32. A palackozott víz egészségesebb, mint a csapvíz.

33. Egy adott étel utáni sóvárgással a testünk jelzi, hogy szüksége van egy bizonyos tápanyagra.

34. A fejtetű az ápolatlan, koszos hajat szereti.

35. A fejtetű át tud ugrani egyik emberről a másikra.

36. Az elhízás hátterében genetikai okok vannak.

37. Az egészséges ember vékony testalkatú.

38. A multivitaminok túladagolhatók.

39. A kövér emberek azért túlsúlyosak, mert túl sokat esznek.

40. A dohányzás nem okoz függőséget.

\begin{tabular}{|c|c|c|c|}
\hline$H$ & 2,92 & $3(40)$ & 3 \\
\hline$H$ & 3,09 & $3(33)$ & 3 \\
\hline $\mathrm{H}$ & 1,88 & $2(30)$ & 2 \\
\hline$H$ & 2,14 & $3(22)$ & 2 \\
\hline $\mathrm{H}$ & 2,06 & $2(25)$ & 2 \\
\hline $\mathrm{H}$ & 1,66 & $1(33)$ & 2 \\
\hline$H$ & 2,84 & $3(40)$ & 3 \\
\hline $\mathrm{H}$ & 2,54 & $2(25)$ & 2 \\
\hline$H$ & 3,04 & $3(28)$ & 3 \\
\hline $\mathrm{H}$ & 2,58 & $2(29)$ & 2 \\
\hline 1 & 3,15 & $4(30)$ & 3 \\
\hline I & 1,90 & $2(25)$ & 2 \\
\hline$H$ & 3,51 & $4(32)$ & 4 \\
\hline I & 3,00 & $3(25)$ & 3 \\
\hline$H$ & 3,64 & $4(32)$ & 4 \\
\hline 1 & 2,97 & $3(35)$ & 3 \\
\hline $\mathrm{H}$ & 1,86 & $1(30)$ & 2 \\
\hline$H$ & 2,66 & $3(46)$ & 3 \\
\hline $\mathrm{H}$ & 1,32 & $1(46)$ & 1 \\
\hline $\mathrm{H}$ & 1,86 & $1(31)$ & 2 \\
\hline$H$ & 2,42 & 3 (29) & 3 \\
\hline$H$ & 3,15 & 3 (39) & 3 \\
\hline I & 1,89 & 1 (27) & 2 \\
\hline$H$ & 3,02 & $4(25)$ & 3 \\
\hline$H$ & 2,94 & $3(56)$ & 3 \\
\hline $\mathrm{H}$ & 2,22 & $2(29)$ & 2 \\
\hline$H$ & 3,11 & $3(42)$ & 3 \\
\hline I & 1,52 & $1(36)$ & 1 \\
\hline$H$ & 2,70 & 3 (47) & 3 \\
\hline $\mathrm{H}$ & 1,41 & $1(45)$ & 1 \\
\hline
\end{tabular}

Forrás: saját szerkesztés

Megjegyzés: „H” jelöli a tudomány jelenlegi állása szerint hamis állításokat, és „I” az igazakat; dőlt „ "H” vagy „।" jelöli azokat az állításokat, ahol az átlagok a téves, illetve az igaz választások túlsúlyát jelzik. 


\section{MEGBESZÉLÉS}

A jelen mérésünk mintaelemszámának alacsony volta miatt nem tudtuk a háttérváltozók szerinti elemzést elvégezni. Az első hipotézisünk vizsgálatára alkalmasnak találtuk a mérőeszközt, hiszen a válaszadók egészségfogalmában a fizikai dimenzió dominált (95,2\%), az érzelmi dimenzió megjelenése ennek harmadát képezte (31,7\%), a társas dimenzió pedig a harmadik leggyakoribb említés volt (17,5\%), a spirituális (9,5\%), a mentális (7,9\%) már $10 \%$ alá került, a társadalmi dimenzió pedig alig jelent meg (1,6\%). Mindez jól érzékelteti az egészségfogalom holisztikus értelmezésének hiányát. Azonban további elemzést igényel az, hogy akik az életmódnak tulajdonították a legerősebb befolyást, milyen egészségfogalommal rendelkeznek. Így következtethetünk arra, hogy az életmód alakításában mely egészségtényezőknek tulajdonítanak nagyobb szerepet válaszadóink. Az életmód fontosságára vonatkozó kérdéssel, elemzéssel is az első hipotézisünkben megfogalmazottakat kívántuk vizsgálni. Amennyiben igazolódik nagymintás kutatásunkban is a fizikai egészségdimenzió túlsúlya, úgy felvetjük annak megfontolását, hogy az iskolai egészségfejlesztés testneveléstől való elválasztása és önálló tantárggyá visszaalakítása kívánatos, mert jelenleg az egészséget a többség csak a fizikális egészséggel azonosítja, amely nagyon fontos elem ugyan, de csak egyike a holisztikus egészségfogalmat alkotó 6 összetevőnek.

Jelen vizsgálatunkban is már kimutatható egészségtévképzetekkel rendelkeztek a válaszadók (62\%), a második hipotézisünk pontosabb vizsgálatára azonban a felsorolt egészségtévképzet-állítások átstrukturálását, valamint néhány állítás egyértelmúbb megfogalmazását látjuk szükségesnek. A harmadik hipotézisünk vizsgálatához jelenleg még folynak az elemzések.

A vizsgálat korlátját jelentette, hogy a szakirodalomban túlnyomórészt a fizikai egészségdimenzióra nézve találtunk állításokat. Ez is azt jelezheti, hogy az emberek gondolkodásában az egészség kapcsán a fizikai dimenzió jelenléte a legaktívabb. Azt is jelentheti azonban, hogy az egészséggel kapcsolatos tévképzetvizsgálatok az eddigiekben csak a fizikai dimenzióra fókuszáltak, így az egyéb dimenziókhoz tartozó téves elképzeléseket nem mérték fel, bár vannak ilyenek is. Az lesz kutatásunk egyik további feladata, hogy mind a hat egészségdimenzióra vonatkozó tévképzeteket tárjunk fel.

\section{KÖVETKEZTETÉSEK}

A téma vizsgálatát egyrészről azért tartjuk szükségesnek, hogy felhívjuk a figyelmet arra, miért is lenne fontos az egészségfejlesztést (korábban egészségtant) mint önálló tantárgyat újra bevezetni a köznevelésben, másrészről a kutatásunk által kimutathatóvá válik, hogy az egészség mely területei kapcsán érdemes többet foglalkozni a leendő pedagógusokkal és így közvetve a diákokkal, hol érdemes a tévképzeteket már az elején tisztázni. Láttatni kivánjuk továbbá, hogy mely forrásokból család, pedagógus, média stb. - szerzik nagyobb részt a pedagógusjelöltek az egyes tévképzeteket, ezáltal megtaníthatjuk nekik, hogyan kezeljék a beérkező információkat.

\section{HIVATKOZÁSOK}

\footnotetext{
${ }^{1}$ Wilfred, C. \& Sutton, Ed. D. (1962). Misconceptions about health among children and youth, School health. 32(9) 347-351.

2 Eggen, P. \& Kauchak, D. (2004). Educational Psychology: Windows, Classrooms. Upper Saddle River: Pearson Prentice Hall.

${ }^{3}$ Martin, R., Sexton, C. \& Gerlovich, J. (2002). Teaching Science for all Children: Methods for Constructing Understanding. Boston: Allyn and Bacon.

${ }^{4}$ Korom, E. (1997). Naiv elméletek és tévképzetek a természettudományos fogalmak tanulásakor. Magyar Pedagógia, 97(1), 19-40.

${ }^{5}$ Korom, E. (2003). A fogalmi váltás kutatása. Iskolakultúra, 8, 84.-94.
} 
${ }^{6}$ Benkő, Zs. (2011). Az egészségfejlesztő szakemberek a magyar közoktatásban. A felsőoktatás válasza. Egészségfejlesztés, LII. évfolyam, 2011. 3. szám.

${ }^{7}$ WHO (1948). Constitution of the World Health Organization. Geneva: World Health Organization. Preamble to the Constitution of WHO as adopted by the International Health Conference, New York, 19 June - 22 July 1946; signed on 22 July 1946 by the representatives of 61 States (Official Records of WHO, no. 2, p. 100) and entered into force on 7 April 1948.

${ }^{8}$ Naidoo, J. \& Wills, J. (1999). Egészségmegőrzés. Medicina Kiadó, Budapest.

${ }^{9}$ Benkő, Zs. (2019). Az egészség történeti és modern megközelítése. Az egészségfejlesztés fogalma, szemléletmódja In: Benkő Zsuzsanna, Lippai László, Tarkó Klára (szerk.): Az egészség az életünk tartópillére. Egészségtanácsadási kézikönyv. JGYF Kiadó. Szeged. 978615594606 06. 15-49.o.

${ }^{10}$ Bedworth, D. A. and Bedworth A. E. (2010): Dictionary of Health Education. Oxford University Press. New York. p. 238.

${ }^{11}$ Korom, E. \& Csapó, B. (1997). A természettudományos fogalmak megértésének problémái. Iskolakultúra, (2), 12.-20.

12 Tóth Zoltán (1999): A kémiatankönyvek mint a tévképzetek forrásai. Iskolakultúra, 9. 10.sz. 103-107.

${ }^{13}$ Kádár, Anett; Farsang, Andrea: Egyetemi hallgatók földrajzzal kapcsolatos tévképzeteinek összehasonlító elemzése. In: VII. Magyar Földrajzi Konferencia kiadványa. Miskolci Egyetem Földrajz Intézete, Miskolc-Lillafüred, pp. 240-255. (2014) ISBN 978-963-358-063-9

${ }^{14}$ Szarvasné Mátó V, \& Benkő Zs. Főiskolai hallgatók egészségképe összehasonlító vizsgálat. Magyar Pedagógia, 2006. 107-127.

${ }^{15}$ VERONIKA, Végh; HENRIETTE, Pusztafalvi. Leendő és gyakorló biológiatanárok egészségdefinícióinak összehasonlító elemzése [Comparative analysis of prospective and practicing biology teachers' health definitions]. Egészségfejlesztés folyóirat, [S.I.], v. 61, n. 1, p. 6-18, márc. 2020. Elérhető: <http://folyoirat.nefi.hu/index.php?journal=Egeszsegfejlesztes\&page=article\&op=view\&path\%5B\%5D=528>. Letöltve: 22 ápr. 2020. doi:http://dx.doi.org/10.24365/ef.v61i1.528.

${ }^{16}$ Németh Anikó, Bársonyné Kis Klára, Lobánov-Budai Éva: Egészségügyi fôiskolai hallgatók egészségfelfogásának vizsgálata. EGÉSZSÉGFEJLESZTÉS 55:(1-2) pp. 28-35. (2014)

${ }^{17}$ Lalonde, M. (1974): A New Perspective on the Health of Canadians. Ottawa, Ontario, Canada: Minister of Supply and Services, Ottawa. 